\title{
A INSUFICIÊNCIA DAS POLÍTICAS PÚBLICAS NO SISTEMA PENITENCIÁRIO PARA RESPONDER AO ESTADO DE COISAS INCONSTITUCIONAL: UM PROBLEMA COMUM A TODOS OS PODERES
}

\author{
THE INSUFFIENCY OF PUBLIC POLICIES IN THE PENITENCIARY SYSTEM \\ TO RESPOND TO THE UNCONSTITUTIONAL STATE OF THINGS: A COMMOM \\ PROBLEM TO ALL THE POWERS
}

André Pereira Crespo*
Marcelo Dias Varella** $^{*}$

\begin{abstract}
Resumo: O objetivo deste artigo é analisar as audiências de custódia como possível solução à superlotação dos presídios brasileiros. O estudo parte da hipótese de o estado de coisas inconstitucional ter origem na insuficiência das políticas públicas até então adotadas pelos poderes públicos. No Executivo Federal, os recursos destinados aos Estados não foram utilizados na construção de novas vagas tampouco melhoraram as condições de cumprimento de pena dos aprisionados. O Legislativo apenas aumenta a incidência do direito penal, a gravidade das penas cominadas e as formas de cumprimento. No Judiciário, houve omissão inconstitucional quando o STF, diante de um pedido abrangente, se restringiu a determinar na ADPF $n .^{\circ} 347$, que juízes e tribunais realizassem audiências de custódia viabilizando a presença do preso perante à autoridade judiciária no prazo máximo de 24 (vinte e quatro) horas e liberou o saldo acumulado do Fundo Penitenciário Nacional para que se cumpra a finalidade para o qual foi criado. A pesquisa pretende responder à seguinte pergunta: a implantação das audiências de custódia sinaliza para a redução do problema do excesso do contingente de presos no sistema carcerário brasileiro? A metodologia é bibliográfica, com foco nas pesquisas acadêmicas e dados empíricos disponibilizados por órgãos oficiais. $\mathrm{O}$ trabalho se diferencia por não se restringir a enfrentar o problema sob a ótica eminentemente teórica, adentrando na análise da realidade brasileira. A contribuição para a compreensão desse grave problema diante de uma proposital omissão dos Poderes Públicos é o resultado pretendido por este artigo.
\end{abstract}

Palavras-chaves: Audiências de custódia. Estado de Coisas Inconstitucional. Humanização. Insuficiência das Políticas Públicas. Sugestões de melhoria.

\begin{abstract}
The purpose of this paper is to analyze custody hearings as a possible solution to the overcrowding of Brazilian prisons. The study starts from the hypothesis that the unconstitutional state of affairs originates from the insufficiency of public policies hitherto adopted by the public authorities. In the Federal Executive, the resources destined to the States were not used in the construction of new vacancies nor improved the conditions of prison sentences. The Legislature only increases the incidence of criminal law, the severity of the sentences imposed and the forms of enforcement. In the judiciary, there was unconstitutional omission when the Supreme Court, upon a broad request, restricted itself to determine in ADPF No. 347 that judges and courts hold custody hearings enabling the presence of the prisoner before the judicial authority within 24 hours and released the accumulated balance of the National Penitentiary Fund to fulfill the purpose for which it was created. The research aims to answer the following question: Does the implementation of

* Agente de Polícia Federal em Brasília. Mestrando em Direito no Centro Universitário de Brasília UniCEUB. E-mail: andrpereiracrespo1@gmail.com

** Livre-Docente pela Universidade de São Paulo. Doutor em Direito pela Universidade de Paris, PanthéonSorbonne. Professor do Programa de Mestrado e Doutorado em Direito do Centro Universitário de Brasília, desde 2002. Pesquisador nível I do CNPq. Realizou estágios de pós-doutorado nos Estados Unidos, nas Universidades da Califórnia, em Berkeley, Georgetown e George Washington. E-mail: marcelodvarella@ gmail.com
\end{abstract}


custody hearings signal the reduction of the problem of the excessive number of prisoners in the Brazilian prison system? The methodology is bibliographic, focusing on academic research and empirical data provided by official bodies. The work is different because it is not restricted to facing the problem from the eminently theoretical point of view, entering the analysis of the Brazilian reality. The contribution to the understanding of this serious problem in the face of a deliberate omission of the Public Powers is the result intended by this article.

Keywords: Custody hearings. State of Things Unconstitutional. Humanization. Insufficiency of Public Policies. Improvement suggestions.

\section{INTRODUÇÃO}

O objetivo deste artigo é a análise das audiências de custódia como possível solução à superlotação dos presídios brasileiros. $\mathrm{O}$ estudo inicia contextualizando o leitor a respeito da situação caótica que se encontra o sistema carcerário brasileiro. A superlotação dos presídios brasileiros tem ocupado as instâncias internacionais comprometidas com os direitos humanos e despertado a atenção de especialistas no campo. O Brasil não melhorou a sua posição entre os países que mais encarceram no mundo. Pelo contrário, a população carcerária no Brasil aumentou de forma espantosa nos últimos 14 anos. Nos anos 2000, o total de pessoas confinadas no sistema penitenciário era de 232.755. De 2000 a 2014 este número cresceu 161\%, e a população carcerária saltou para 607.731 (ZACKSESKI et al., 2016, p. 291-331).

O Relatório Global Peace Index 2018 (Índice Global de Paz 2018, em tradução livre), publicado em 6 de junho de 2018, avaliou a paz em 163 países abrangendo 99,7\% da população mundial. Cazarré (2018) aponta que o mundo hoje tem o pior índice de paz da última década. O Brasil ocupa a $106^{\mathrm{a}}$ posição e sofre com altos índices de criminalidade e corrupção. O sistema carcerário brasileiro reflete esse cenário brasileiro. As prisões brasileiras são precárias, comprometem a função ressocializadora da pena e o retorno do cidadão recuperado ao convívio social.

O Conselho Nacional do Ministério Público (CNMP) (BRASIL, 2015) noticia que o ano de 2016 terminou com taxa de ocupação dos presídios brasileiros de 161,91\%. As construções comportariam 412.897 presos, mas terminaram o ano de 2016 com 668.523 , considerando o total de 1.456 estabelecimentos penais no país. Nesses dados estão computados apenas os presos que ocupam vagas no sistema prisional. Foi desconsiderado o número de presos em cumprimento de prisão domiciliar.

O estudo deste artigo parte da hipótese de que a principal causa do atual estado de coisas inconstitucional do sistema penitenciário brasileiro ser a insuficiência das políticas públicas adotadas pelos poderes públicos.

Após a contextualização do problema, o tópico seguinte trata da ação inconstitucional do Poder Legislativo. A política recorrente desse Poder é avançar com normas criminalizadoras de infrações e ampliar o número de pessoas presas, em que pese o caráter subsidiário do direito penal. A grande maioria dos projetos em direito penal reafirma a necessidade de agravamento do preceito sancionatório como meio de assegurar resposta adequada ao crime e, especialmente, prevenir novos delitos.

$\mathrm{Na}$ sequência, discorre-se a respeito das ações inconstitucionais do Poder Executivo. No âmbito desse Poder, falta capacitação dos gestores estaduais e federais para construção de presídios. 
As regras para construção de presídios são distantes da realidade do país, inexistem orientações técnicas para atendimento aos editais e faltam empresas especializadas que atendam aos requisitos previstos. Além disso, não há modelos uniformizados de projetos e há até mesmo certo preconceito em relação à destinação dos recursos para a melhoria do sistema carcerário em detrimento de outras áreas possíveis para realização de políticas públicas.

No tópico seguinte, o enfoque da análise é o Poder Judiciário. O Pacto Internacional sobre Direitos Civis e Políticos (PISDCP) foi adotado pela XXI Sessão da Assembléia-Geral das Nações Unidas em 16 de dezembro de 1966. A Convenção Americana sobre Direitos Humanos (CADH) havia sido assinada na Conferência Especializada Interamericana sobre Direitos Humanos, em San José na Costa Rica em 22 de novembro de 1969. É importante notar que em 2015 o Brasil se aproximava de 50 anos de inobservância do PISDCP e da CADH.

Durante todo esse período, a falta de ação até mesmo do Judiciário para assegurar o cumprimento dos direitos fundamentais dos presos cristaliza uma inação inconstitucional por parte desse Poder. Foram quase 50 anos de violações do direito de acesso à justiça dos presos, na medida em que eles foram privados de serem vistos, ouvidos e sentidos por uma autoridade judicial imediatamente após ao ato de prisão. A omissão continuou quando o STF deixou de tutelar os direitos fundamentais dos presos, conforme deduzidos em juízo nos moldes abrangentes propostos na petição inicial da ADPF n. ${ }^{\circ}$ 347-DF.

Até então, vigorava no Brasil o procedimento cartorial de mero encaminhamento do auto de prisão em flagrante para análise do juiz. Em setembro de 2015, o STF determinou a implementação das audiências de custódia com a finalidade de ajustar a legislação processual penal brasileira às exigências de diplomas internacionais, tentar evitar casos de violência policial, prisões ilegais, arbitrárias ou desnecessárias, impactando, principalmente, no número de presos provisórios (VASCONCELLOS, 2016).

Pode-se afirmar que a implantação das audiências de custódia causou a disruptura com o modelo cartorial de comunicação das prisões provisórias até então vigente e promoveu humanização ao processo penal. Um dos efeitos esperados da implantação da audiência de custódia no sistema processual brasileiro é a redução da superpopulação carcerária, nos termos da Resolução n. ${ }^{\circ}$ 213/2015 do Conselho Nacional de Justiça (BRASIL, 2016).

O trabalho não realiza aprofundamento teórico sobre as audiências de custódia. Analisa dados empíricos de forma ampla. A metodologia foi bibliográfica, com foco nas pesquisas acadêmicas e dados empíricos disponibilizados por órgãos oficiais após a implantação das audiências de custódia.

A pesquisa se justifica pela previsão expressa no texto da Resolução no 213/2015 do Conselho Nacional de Justiça (CNJ) (BRASIL, 2016) de que as audiências de custódia se apresentam como política pública com potencial para reduzir o contingente de presos provisórios no Brasil.

Diante do cenário caótico do sistema prisional, a pesquisa pretende responder à seguinte pergunta: a implantação das audiências de custódia sinaliza para a redução do problema do excesso do contingente de presos no sistema carcerário brasileiro?

A implantação das audiências de custódia revolucionou o processo penal brasileiro nos últimos anos, causou disruptura com o modelo cartorial de comunicação das prisões provisórias 
até então vigente e incrementou maior humanização ao processo penal brasileiro (TÁVORA; ALENCAR, 2016, p. 915).

Passados pouco mais de 4 anos da implantação das audiências de custódias, conforme os dados disponibilizados pelos órgãos oficiais, parece ainda não haver substancial repercussão na resolução do problema da superlotação dos presídios brasileiros. Cientes da importância do aprofundamento da análise sugerimos pesquisas individualizadas no âmbito de cada unidade da federação para se chegar a um diagnóstico mais preciso considerando-se as peculiaridades locais.

Diante de problemas tão graves no sistema prisional, entendemos a audiência de custódia como importante instrumento para se evitar a banalização da prisão provisória e amenizar o superencarceramento no sistema penitenciário. O êxito do desafio de cessar as violações a direitos fundamentais do preso passa por colocar a questão prisional como prioridade na formulação das políticas públicas pelos integrantes do cenário político brasileiro.

\section{O CAOS NO SISTEMA PENITENCIÁRIO}

A situação carcerária no Brasil é caótica. As prisões brasileiras superlotadas violam garantias fundamentais previstas na Constituição da República e nos tratados assinados pelo Brasil. Entre 1990 e 2013, o crescimento da população carcerária foi de 507\%, a segunda maior taxa de crescimento prisional do mundo, mas ainda há déficit de 206.307 vagas no sistema carcerário (BRASIL, 2014).

A temática da superlotação de presídios tem ocupado as instâncias internacionais comprometidas com os direitos humanos. Nesse particular, as Nações Unidas têm atraído para si posição de nítido protagonismo. O superencarceramento ou encarceramento em massa compõe a literatura jurídico-penal há tempo considerável (SUXBERGER, 2016, p. 1).

Pesquisas realizadas no InfoPen revelam que a população carcerária brasileira é constituída em sua maioria por pobres e negros e alcançou, em maio de 2014, 711.463 presos, incluídos 147.397 em regime domiciliar, para 357.219 vagas disponíveis. Desconsiderando o número de presos em domicílio, segundo essa fonte, o déficit é de 206.307 vagas $^{1}$.

Embora a posição do Brasil em relação aos outros países que mais encarceram no mundo não tenha se alterado de 2008 para 2015, já se observou que a população carcerária no Brasil aumentou de forma espantosa nos últimos 14 anos. Nos anos de 2000 o total de pessoas confinadas no sistema penitenciário era de 232.755. De 2000 a 2014 este número cresceu 161\%, e a população carcerária saltou para 607.731 (ZACKSESKI et al., 2016, p. 291-331)

O índice de criminalidade em elevação constante e o evidente descrédito na ação estatal de promoção da paz e tranquilidade públicas são grandezas que, na atualidade, estão diretamente relacionadas. A fim de combater esses problemas, políticas específicas de recrudescimento da resposta penal têm sido, frequentemente, empregadas pelo Parlamento brasileiro como técnica de enfrentamento e de combate ao crime (SUXBERGER; LIMA, 2017, p. 277-293).

O relatório Global Peace Index 2018 (Índice Global de Paz 2018, em tradução livre), publicado em 6 de junho de 2018, avalia a paz em 163 países abrangendo 99,7\% da população mundial. O Brasil ocupa a $106^{\text {a }}$ posição, sofre com altos índices de criminalidade e corrupção e obteve leve 
melhora no ranking em relação a 2017, quando estava em $108^{\circ}$. O mundo hoje tem o pior índice de paz da última década (CAZARRÉ, 2018).

No mundo todo, as mortes em conflito aumentaram $264 \%$ nos últimos dez anos. A América do Sul registrou a segunda maior taxa de homicídios entre as regiões do globo, ficando atrás apenas da América Central e do Caribe. O Chile e o Uruguai apresentaram as melhores posições no ranking da América do Sul, ocupando a $28^{\mathrm{a}}$ e a $37^{\mathrm{a}}$ posições, respectivamente.

Entre os latino-americanos, o Brasil ficou à frente apenas da Venezuela $\left(143^{\circ}\right)$ e da Colômbia $\left(145^{\circ}\right)$. Dos 23 indicadores analisados no documento, o Brasil obteve os piores resultados em homicídios, percepção da criminalidade, acesso às armas, crimes violentos e terror político. O sistema carcerário, além de refletir esse cenário brasileiro, é precário e, como consequência, compromete a função ressocializadora da pena e o retorno do cidadão recuperado ao convívio social.

É importante registrar que, historicamente, é alto o número de prisões cautelares no Brasil, fator que contribui para agravar ainda mais a caótica situação carcerária. Em 2011, com o advento da Lei $\mathrm{n}^{\mathrm{0}}$ 12.403/11, foram inseridas no ordenamento jurídico novas medidas cautelares diversas da prisão. Pela lógica, tais medidas deveriam desafogar o sistema carcerário no Brasil. No entanto, mesmo com a implantação dessas medidas, o número de prisões provisórias não parou de crescer (AGÊNCIA, 2018).

Segundo dados oficiais fornecidos pelo CNJ, até junho de 2017 foram realizadas 258.485 audiências de custódia no Brasil, das quais 115.497 (44,68\%) resultaram em concessão da liberdade e 142.988 (55,32\%) em prisão preventiva. Em 12.665 (4,90\%) audiências de custódia houve alegação de violência no ato da prisão (BRASIL, 2014). É uma sinalização de que as audiências de custódia não estão contribuindo para amenizar o problema da superlotação nos presídios, tendo em vista que mais da metade das prisões provisórias foram confirmadas pelas autoridades judiciais.

Há periodicamente relatórios descritivos e analíticos divulgados por meio do InfoPen em que o Departamento Penitenciário Nacional (DEPEN) e a Secretaria Nacional de Segurança Pública (SENASP) tentam mensurar e analisar o sistema carcerário brasileiro. O Conselho Nacional do Ministério Público (CNMP) também passou a divulgar dados referentes à população carcerária brasileira. Em relação especificamente às audiências de custódia, o CNJ divulga em seu sítio eletrônico informações compiladas que podem nos revelar importantes informações no direcionamento a uma política pública mais efetiva de recuperação do preso.

Comparado a outros países e considerando-se as prisões domiciliares, o Brasil tem a $3^{\mathrm{a}}$ maior população carcerária do mundo, depois dos Estados Unidos e da China. Caso se considere apenas o número de presos em presídios e delegacias, o Brasil fica em quarto lugar, logo após a Rússia ${ }^{2}$.

O Brasil ocupa o $4^{\circ}$ lugar no ranking mundial de países com maiores taxas de aprisionamento. Segundo dados do InfoPen 2014 (BRASIL, 2014), existem cerca de 300 presos para cada cem mil habitantes no país. O número de presos é consideravelmente superior às 377 mil vagas do sistema penitenciário, totalizando um déficit de 231.062 vagas e uma taxa de $161 \%$ de ocupação média dos estabelecimentos. Em outras palavras, em um espaço concebido para custodiar 10 pessoas, existem por volta de 16 indivíduos encarcerados. Feito um recorte de gênero, a população absoluta de mulheres encarceradas no sistema penitenciário cresceu 567\% entre os anos 2000 e 2014, chegando ao patamar de 37.380 mulheres. A deficiência de vagas poderia ser pior não fossem os 373.991 mandados de prisão expedidos esperando cumprimento, dos quais $41 \%$ são provisórios. 
O aumento de penas para crimes de menor potencial ofensivo vai de encontro a uma estratégia de gestão global dos riscos e de administração do sistema penitenciário.

O sítio eletrônico do CNMP (BRASIL, 2015) noticia que o ano de 2016 terminou com taxa de ocupação dos presídios brasileiros de 161,91\%. Segundo o levantamento, as construções comportariam 412.897 presos, mas terminaram o ano de 2016 com 668.523 , considerando o total de 1.456 estabelecimentos penais no país. Nesses dados estão computados apenas os presos que ocupam vagas no sistema prisional. Foram desconsiderados os presos em cumprimento de prisão domiciliar.

Gráfico 1: Déficit de vagas no Sistema Prisional - CNMP

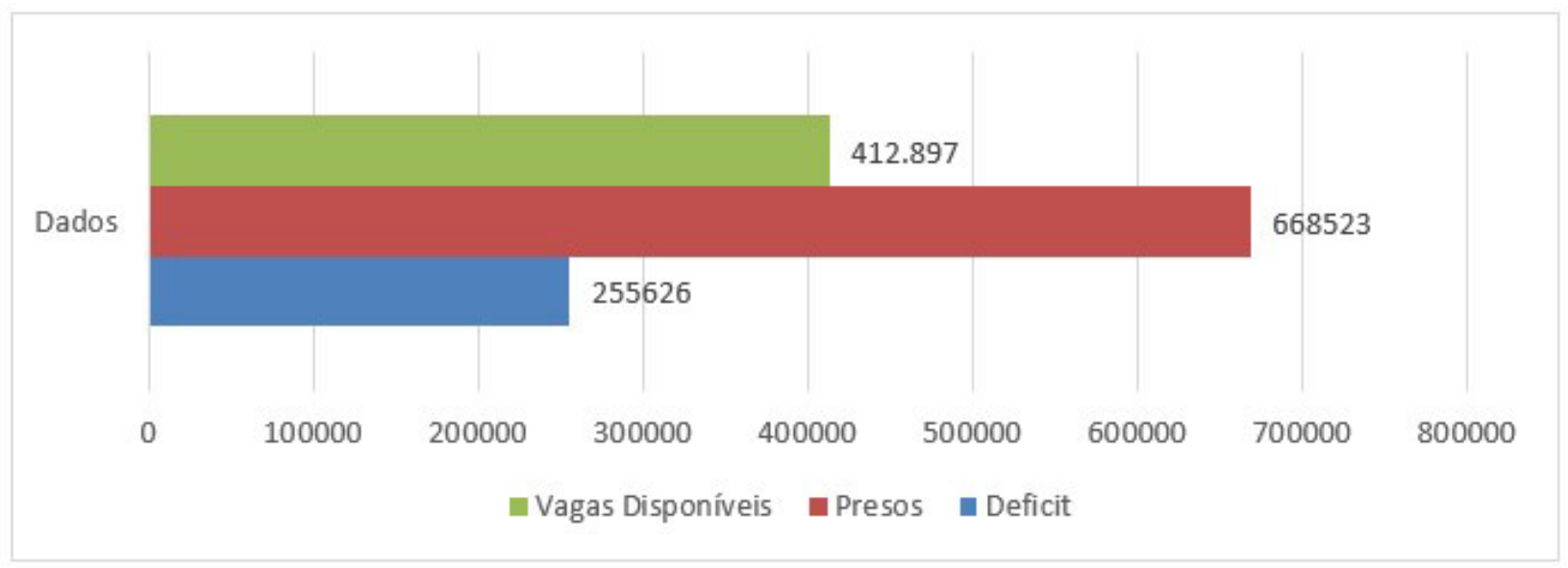

Fonte: Elaboração própria.

Em relação ao mesmo ano, o site do Ministério da Justiça (BRASIL, 2017a) informa que havia no Brasil, desconsiderando prisões domiciliares, 726.712 pessoas presas, quando eram oferecidas 368.049 vagas. O déficit, portanto, seria de 358.663 vagas naquele momento e a taxa de ocupação era de 197,4\%.

Gráfico 2: Déficit de vagas no Sistema Prisional - MJ

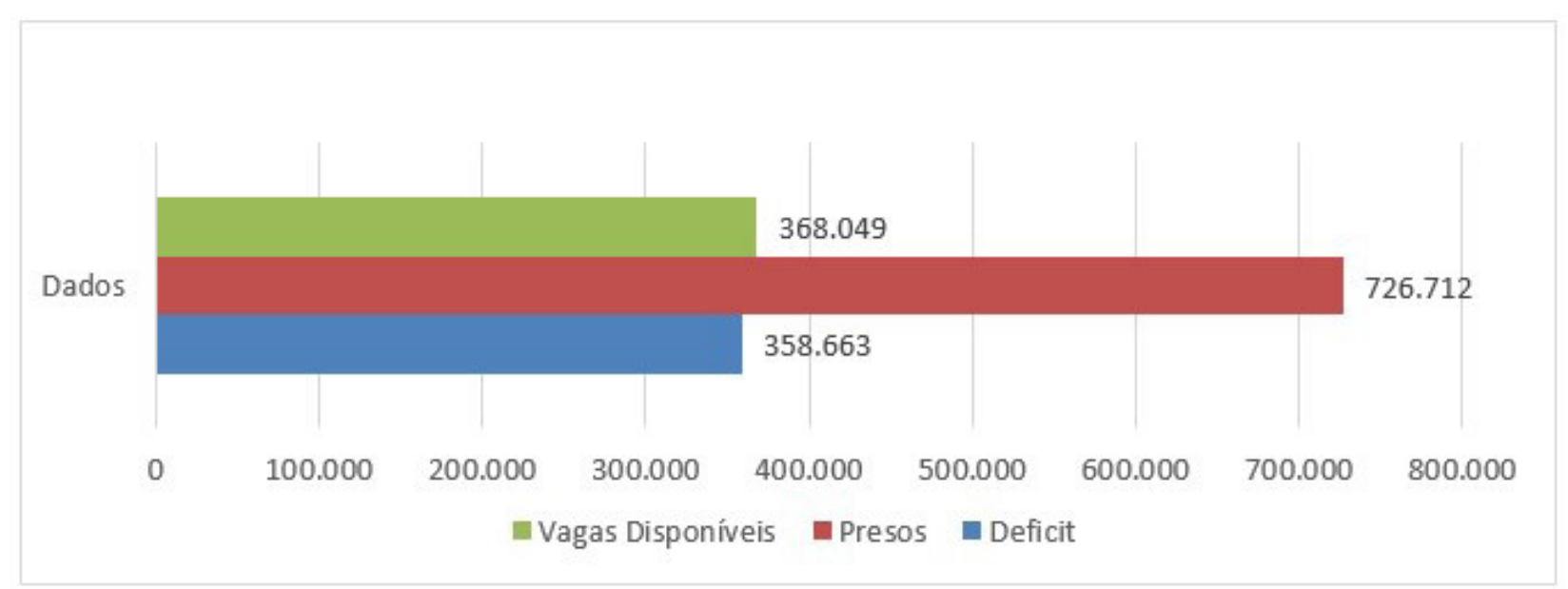

Fonte: Elaboração própria. 
Como se não bastasse a divergência apontada, em levantamento realizado pelo CNJ com os tribunais de justiça estadual, finalizado em janeiro de 2017 (BRASIL, 2017) referente ao ano anterior, o Brasil teria 654.372 presos dos quais 433.318 (66\%) eram condenados e 221.054 (34\%) eram provisórios.

Essas divergências sinalizam que os dados fornecidos pelo Poder Executivo e pelo Poder Judiciário não são confiáveis. O Judiciário tem dados e metodologias distintas para avaliação da quantidade de presos provisórios. Os sistemas eletrônicos de controle de presos não dialogam entre si. O controle biométrico, realizado com acurácia pela precisa Justiça Eleitoral, por variados obstáculos burocráticos não consegue chegar aos presos. O Sistema de Informações do Departamento Penitenciário Nacional (SISDEPEN) não é preenchido corretamente em vários Estados e os módulos que permitiriam uma gestão mais efetiva dos presídios e controle da aplicação das penas não foram desenvolvidos. Ainda há Estados que controlam seus presos em planilhas de Excel e não há conferência precisa da identidade de cada indivíduo, de modo que os próprios agentes institucionais do sistema acreditam que o índice de falsas identidades entre os presos supere $25 \%$.

Para maior eficácia da política pública de melhoria do sistema carcerário é salutar que seja feito levantamento real do número de presos. A melhor solução seria a implementação completa do Banco Nacional de Monitoramento de Prisões (BRASIL, [2019?]), sistema nacional integrado com o cadastramento biométrico dos presos cujos dados são alimentados pelos Estados.

\section{A AÇÃO INCONSTITUCIONAL DO PODER LEGISLATIVO: A CRIMINALIZA- ÇÃO DA VIDA E O AUMENTO DE PENAS}

Todo crime será hediondo, todas as penas serão gravíssimas, toda infração será de natureza penal (NUCCI, 2013, p. 389). O Poder Legislativo avança com centenas de normas que criminalizam infrações antes de natureza administrativa, ampliando o número de pessoas presas. A grande maioria dos projetos em direito penal afirma a necessidade de reforço e agravamento do preceito sancionatório como meio de assegurar resposta adequada ao crime e, especialmente, prevenir novos delitos. A intervenção penal guarda legitimação jurídica por meio da exclusiva proteção de bens jurídicos e, pela tipificação de condutas, atribuir resposta adequada ao crime e prevenir o cometimento de novos delitos. É bastante superada a concepção de que apenas o incremento dos preceitos sancionatórios implica efeito dissuasório da prática de crimes (ROXIN, 2008, p. 15-19). Ao contrário, para Prado (2014, p. 42), o Estado brasileiro filia-se por determinação constitucional a um Direito Penal de cariz subsidiário, isto é, um Direito Penal cuja intervenção se realize como medida mais extrema de controle social formal pelo Estado ${ }^{3}$.

A promoção de reformas na legislação penal para criação de delitos e majoração de penas merece cautela. A expansão desmedida e a constante alteração dos tipos penais reduzem a liberdade individual e a segurança jurídica; agravam a crise da superlotação prisional, com reflexos no aumento da reincidência e da criminalidade; e geram inconsistências no ordenamento jurídico.

Há atualmente cerca de 1.688 hipóteses de criminalização primária distribuídas pelo Código Penal e dezenas de outras leis especiais. Nesse ponto é interessante lembrar a oposição feita por Liszt (1905, p. 126) entre o direito penal e política criminal. Segundo o autor, “o direito penal só 
será ciência jurídica em sentido próprio, enquanto se ocupar da análise conceitual das regulamentações jurídico-positivas e da sua ordenação no sistema. A política criminal, que se importa com os conteúdos sociais fins do direito penal, encontra-se fora do âmbito jurídico". No que se refere especificamente à execução penal, chamada por Liszt como "o espaço quase livre do direito" (der quase rechtsfreie Raum), ele tentou influenciá-la de modo socialmente reformador com sua conhecida doutrina dos tipos de autor.

Desde a promulgação da Constituição de 1988 até agosto de 2015, foram editadas 77 leis ordinárias e complementares criando tipos penais em leis extravagantes ou em artigos do Código Penal. Neste trabalho, abusaremos do uso dos indicadores, em sintonia com o pensamento de Roxin (2008, p. 56), quando se colocou como defensor de "uma extensa utilização de dados empíricos na sistemática e na dogmática das teorias gerais do direito penal".

Das 579 novas normas penais aprovadas pelo Congresso Nacional nos últimos anos, quase todas criaram novos crimes ou aumentam penas (531 e 39, respectivamente) e apenas duas normas reduziram penas (BRASIL, 2015a).

Tabela 1: Normas de comportamento: distribuição por lei de destino

\begin{tabular}{|l|l|l|}
\hline Lei de destino & Criação & Extinção \\
\hline Código Penal & 32 & 0 \\
\hline Legislação Especial & 121 & 0 \\
\hline Lei nova & 378 & 0 \\
\hline Total & $\mathbf{5 3 1}$ & 0 \\
\hline
\end{tabular}

Fonte: Ministério da Justiça e Cidadania.

Tabela 2: Modificação das normas de comportamento

\begin{tabular}{|l|l|l|}
\hline Lei de destino & \multicolumn{2}{|l|}{ Modificação de normas de comportamento } \\
\hline & 20 & Redução \\
\hline Código Penal & 19 & 0 \\
\hline Legislação especial & 19 & 2 \\
\hline Lei nova & - & 0 \\
\hline Total & $\mathbf{3 9}$ & 2 \\
\hline
\end{tabular}

Fonte: Ministério da Justiça e Cidadania.

Em que pese a tendência de enrijecimento das leis penais brasileiras, a redução da pobreza e a melhoria dos índices sociais durante o mesmo período, vê-se que a violência no Brasil tem evoluído com rapidez assustadora, tendência contrária a dos movimentos de reformas punitivistas das últimas décadas na Europa. Na Espanha, por exemplo, a partir de 1978, desapareceram diversas 
infrações penais. Trata-se de mudança estrutural de orientação político-criminal, conforme adverte Jakobs (2008, p. 60).

Dados indicam que o surgimento de novos tipos penais, a elevação de penas, a criação de qualificadoras e de outros mecanismos voltados ao encarceramento não influenciam na diminuição da criminalidade. Pelo contrário, entre os anos de 1980 e 1984 ocorriam 14,8 homicídios por 100 mil habitantes no Brasil. De acordo com a pesquisa Indicadores de Desenvolvimento Sustentável (IDS 2012), elaborada pelo Instituto Brasileiro de Geografia e Estatística (IBGE) em 2009, esse número subiu para 27,1 por 100 mil habitantes. Em pesquisa de 2014 de Sachsida e Mendonça (2014), durante o mesmo período em que se registrou o aumento de tipos penais e endurecimento de penas, o número já estava em 46,2 por 100 mil habitantes, ou 3 vezes a média mundial, representando ampliação de $83,1 \%$ na taxa de homicídios em trinta anos.

Sobre o estado atual da política criminal, as características principais da política criminal praticada nos últimos anos podem resumir-se no conceito de expansão do Direito Penal. Efetivamente, no momento presente pode ser adequado que o fenômeno mais destacado na evolução corrente das legislações penais do mundo ocidental seja o surgimento de múltiplas figuras novas, inclusive, às vezes, de setores inteiros de regulação, acompanhado de uma atividade de reforma de tipos penais existentes, realizada a um ritmo muito superior ao de épocas anteriores (JAKOBS, 2008, p. 56).

A ineficiência de alterações endurecedoras da legislação penal pode ser observada na análise dos crimes contra a dignidade sexual. Em 2009, foi sancionada a Lei nº 12.015 (BRASIL, 2009), que passou a tratar o estupro - assim também previsto na Lei 8.072/90 (BRASIL, 1990) - como crime contra a dignidade e liberdade sexual, inserindo no Código Penal o Título VI - Dos Crimes Contra a Dignidade Sexual. A modificação aumentou a pena do crime de estupro de três a oito anos para seis a dez anos. Muito embora tenha ocorrido o enrijecimento das sanções penais e o acréscimo de tipos penais, como revelado acima, a taxa de estupro por 100 mil habitantes subiu de 18 para 22, ou de 33.912 para 45.460 casos por ano, conforme dados do Fórum Brasileiro de Segurança Pública ([2016?]).

Em oposição ao esperado por grande parte da população e dos legisladores, a multiplicação de leis criminalizadoras não é acompanhada de uma diminuição dos índices de violência. Ao contrário, no Brasil, o aumento das penas foi acompanhado pelo aumento do número de crimes. A sensação de insegurança atinge $70 \%$ dos brasileiros e é a maior do mundo ${ }^{4}$. A sensação de risco determina uma tendência de formação de um Direito Penal hipertrofiado, prevencionista e expansivo.

A multiplicação de leis que tipificam novas condutas, elevam penas e criam qualificadoras não são capazes de reduzir os índices de criminalidade (ROXIN, 2008, p. 16). Pelo contrário, a sensação de insegurança pública aumenta constantemente. Objetivamente, as reformas penais endurecedoras costumam produzir efeito positivo efêmero logo após a aprovação, mas em seguida a criminalidade retorna com toda intensidade. Exemplo da ineficácia da política de agravamento de sanções a médio e a longo prazo é a ascensão das taxas de homicídios após a publicação da Lei de Crimes Hediondos: 
Gráfico 3: Evolução da taxa de homicídios dolosos

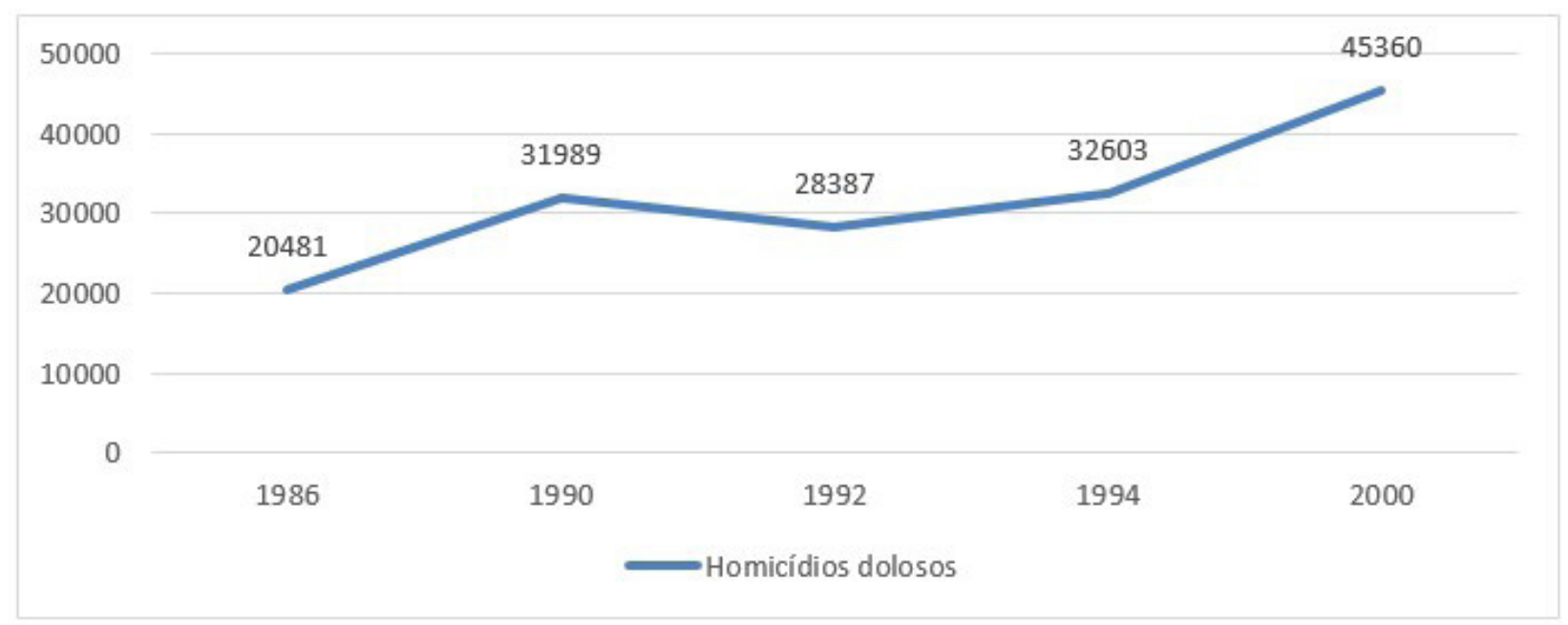

Fonte: Mapa da violência - 2016

O agravamento das sanções e a introdução de novos tipos penais expande a população prisional e intensifica a crise da superlotação carcerária que o país enfrenta.

O Brasil é signatário de uma série de atos normativos internacionais, aos quais se vincula sua produção legislativa interna. É preciso reconhecer igualmente a crescente importância do Estado brasileiro no plano internacional em relação aos atos de proteção e promoção dos direitos humanos. Nessa linha de ideias, destacam-se as chamadas Regras de Tóquio: regras mínimas padrão das Nações Unidas para a elaboração de medidas não privativas de liberdade, formalizadas no Anexo da Resolução n ${ }^{\circ}$ 45/110 da Assembleia Geral das Nações Unidas. As Regras de Tóquio trazem como objetivo fundamental que

os Estados-Membros devem desenvolver em seus sistemas jurídicos medidas não privativas de liberdade para proporcionar outras opções e assim reduzir a utilização do encarceramento e racionalizar as políticas de justiça criminal, levando em consideração a observância aos direitos humanos, as exigências da justiça social e as necessidades de reabilitação dos infratores (CONSELHO, 2016, p. 15).

Além disso, as penas privativas de liberdade "devem ser aplicadas de acordo com o princípio da intervenção mínima” (CONSELHO, 2016, p. 16). É relevante destacar que, por força das Regras de Tóquio, o Estado brasileiro deve dotar as autoridades judiciárias de amplas possibilidades de utilização de medidas alternativas ao uso da prisão. Por ser tratado de direitos humanos, tem valor supralegal no ordenamento jurídico brasileiro e deve ser aplicado.

A intervenção mínima do sistema penal na América Latina é mandatória em respeito aos compromissos internacionais assumidos pelo Brasil. Além disso, em relação à necessária intervenção mínima do sistema penal na América Latina, Zaffaroni e Pierangeli (2015) defendem que, por aumentar as contradições e a violência interna, a ingerência penal estatal acarreta um genocídio interno que pode causar a destruição do sistema produtivo, minando o próprio direito ao desenvolvimento. Para os autores, o excesso de ingerência penal, portanto, é fator agravante do subdesenvolvimento e da violência dos países periféricos (ZAFFARONI; PIERANGELI, 2015, p. 79). 
É preciso considerar perspectivas que efetivamente produzam resultados na realidade social e tragam maior controle dos instrumentos do crime, melhoria das polícias, disseminação do uso de técnicas de perícia criminal, punição efetiva de crimes com violência e grave ameaça e mecanismos alternativos de cumprimento de pena para réus primários em crimes sem violência ou grave ameaça.

Para aumento do controle social, medidas legislativas alternativas à criação de delitos são mais eficientes na redução de criminalidade do que novos tipos penais e majorações de pena. Tomando como apenas um exemplo, os homicídios praticados com arma de fogo, nota-se que $85 \%$ daquelas encontradas em posse dos criminosos são anteriores ao Estatuto do Desarmamento (Lei $\mathrm{n}^{\mathrm{o}}$ 10.826, de 2003) e os números de homicídios com armas de fogo tiveram significativa queda e redução da variação anual, conforme gráfico a seguir do Mapa da violência de 2016 (WAISELFISZ, 2015):

Gráfico 4: Taxas de homicídios com emprego de arma de fogo (por 100.000) - 1980/2014

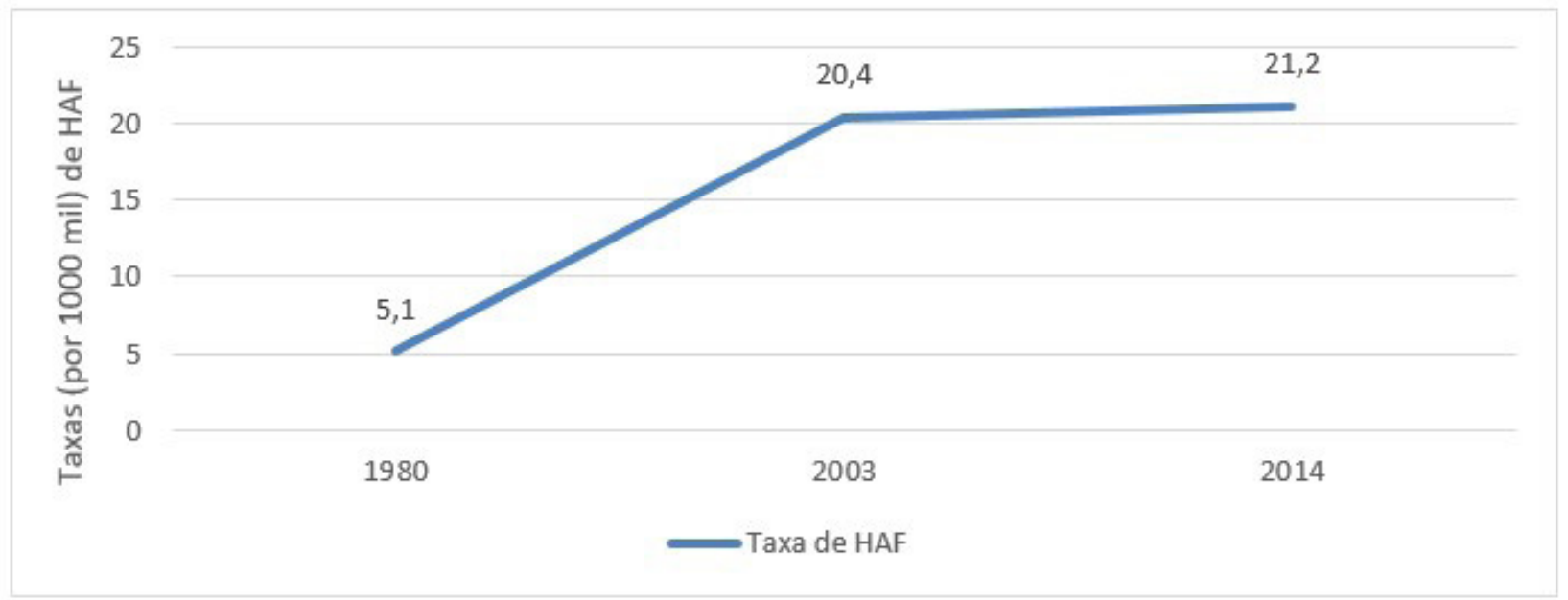

Fonte: Waiselfisz, 2015.

Ademais, as incessantes alterações pontuais do Código Penal geram situações de desproporcionalidade entre as penas em abstrato: não é proporcional que a violência perpetrada contra o ser humano seja punida de maneira mais leve que a lesão a bens patrimoniais. Tais incongruências derivam da proliferação de reformas meramente endurecedoras que não levam em conta a integralidade da legislação atual.

O pretendido efeito dissuasório de novos crimes, justificativa maior do Projeto, somado ao sentimento de satisfação daqueles atingidos pela prática criminosa não se mostram adequados à ação estatal deduzida no Projeto em epígrafe. O Estado brasileiro igualmente vincula-se ao Escritório das Nações Unidas sobre Drogas e Crime (UNODC), cujo trabalho se ampara nas três convenções internacionais de controle de drogas e as convenções contra o crime organizado transnacional e contra a corrupção, todas internalizadas formalmente no Direito pátrio.

No campo de segurança pública, o UNODC trabalha para ampliar a capacidade dos países em oferecer uma resposta à criminalidade. Ainda com o suporte e apoio do Estado brasileiro, elaborou um compêndio de princípios e normas gerais sobre prevenção do crime e Justiça criminal 
(Compendium of United Nations Standards and Norms in Crime Prevention and Criminal Justice), atualizado periodicamente para melhor refletir os desafios que se põem aos países que integram e se vinculam a ele. Também o UNODC é claro na indicação de que as medidas de prevenção de crimes devem se ocupar da promoção de medidas situacionais (tais como redução de oportunidades para práticas delituosas), promoção de ações de bem-estar e enfrentamento de quadros de exclusão social, promoção de valores comunitários e respeito a direitos humanos em sua dimensão mais básica, promoção de responsabilidade cívica e procedimentos de mediação social, facilitação de métodos de trabalho articulado entre polícias e atores do sistema de justiça criminal.

O recurso extremado de incremento das penas, afasta-se de preceitos reconhecidamente efetivos no enfrentamento da criminalidade e deve reservar-se aos casos em que se mostre proporcional em face daqueles crimes já apenados de forma mais severa e que protegem bens jurídicos primários ou nucleares (tais como a vida, a integridade física e a dignidade sexual).

O princípio da lesividade deve levar à deflação dos bens penais e das proibições. Por seu caráter restritivo e minimizador, sua observância acarretaria a redução dos tipos penais existentes e de sua extensão, em sentido oposto ao crescente e descontrolado número de propostas penais endurecedoras em trâmite no Brasil:

Um programa de direito penal mínimo deve apontar a uma massiva deflação dos "bens" penais e das proibições legais, como condição da sua legitimidade política e jurídica. É possível, também, que nesta reelaboração fique evidenciada a oportunidade, em função da tutela de bens fundamentais, de uma maior penalização de condutas hoje não adequadamente proibidas nem castigadas: por exemplo, a introdução de um delito específico de tortura (exigência expressa do art. $13, \S 4 .^{\circ}$ da Constituição) diante da tendência jurisprudencial de ludibriar sua punição ou a criação de novos delitos ambientais. Entretanto, nosso princípio de lesividade, tal como resulta dos critérios já comentados, atua como uma afiada navalha descriminalizadora, idônea para excluir, por injustificados, muitos tipos penais consolidados, ou para restringir sua extensão por meio de mudanças estruturais profundas. Agora irei me referir, em particular, a três classes de delitos a respeito dos quais se realiza esta função restritiva e minimizadora.

$[\ldots]$

Em conclusão, o princípio de lesividade, como ficou aqui definido, tem o valor de critério polivalente de minimização das proibições penais. E equivale a um princípio de tolerância tendencial da desviação, idôneo para reduzir a intervenção penal ao mínimo necessário e, com isso, para reforçar sua legitimidade e credibilidade. Se o direito penal é um remédio extremo, devem ficar privados de toda relevância jurídica os delitos de mera desobediência, degradados à categoria de dano civil os prejuízos reparáveis e à de ilícito administrativo todas as violações de normas administrativas, os fatos que lesionam bens não essenciais ou os que são, só em abstrato, presumidamente perigosos, evitando, assim, a "fraude de etiquetas", consistente em qualificar como "administrativas" sanções restritivas da liberdade pessoal que são substancialmente penais (FERRAJOLI, 2002, p. 381-384).

Nesse sentido, no julgamento da Ação Direta de Inconstitucionalidade 3112, o Supremo Tribunal Federal indica a inconstitucionalidade das normas que aumentam penas de forma incongruente, irrazoáveis, pela inadequação entre meios e fins. A proposta em tela apresenta-se inconstitucional por ferir o princípio da proporcionalidade, ou seja, da apreciação entre a necessidade e a providência adotada. Na oportunidade, discutiu-se a constitucionalidade da Lei no 10.826 de 2003 (Estatuto do Desarmamento), tendo o Ministro Gilmar Mendes proferido voto destacando a importância de se observar o princípio da proporcionalidade na atuação do legislador em matéria penal: 
No âmbito do controle de constitucionalidade em matéria penal, deve o Tribunal, portanto, na maior medida possível, inteirar-se dos diagnósticos e prognósticos realizados pelo legislador na concepção de determinada política criminal, pois do conhecimento dos dados que serviram de pressuposto da atividade legislativa é que é possível averiguar se o órgão legislativo utilizou-se de sua margem de ação de maneira justificada.

No terceiro nível, o controle material de intensidade aplica-se às intervenções legislativas que, a exemplo das leis penais, por afetarem intensamente bens jurídicos de extraordinária importância, como a liberdade individual, devem ser submetidas a um controle mais rígido por parte do Tribunal.

Os mandatos constitucionais de criminalização, portanto, impõem ao legislador, para o seu devido cumprimento, o dever de observância do princípio da proporcionalidade como proibição de excesso e como proibição de proteção insuficiente. A ideia é a de que a intervenção estatal por meio do Direito Penal, como ultima ratio, deve ser sempre guiada pelo princípio da proporcionalidade.

A reserva de lei penal configura-se como reserva legal proporcional [...]: a proibição de excesso [...] funciona como limite máximo, e a proibição de proteção insuficiente, $[. .$. como limite mínimo da intervenção legislativa penal.

\section{A AÇÃO INCONSTITUCIONAL DO PODER EXECUTIVO}

No âmbito do Poder Executivo, foram adotadas diversas iniciativas para tentar reduzir o problema da superlotação carcerária, como o envio ao Congresso Nacional de Medidas Provisórias que facilitaram os gastos em segurança pública e construção de presídios.

Com a MP 759 e depois a MP 689, convertida na Lei $n^{\circ} 13.500$ de outubro de 2017:

a. tornou o Fundo Penitenciário Nacional (FUNPEN) incontingenciável;

b. permitiu a execução descentralizada, por meio de transferências diretas aos Fundos Penitenciários Estaduais;

c. possibilitou licitações para construção de presídios sem licitação.

O FUNPEN tornou-se um dos únicos Fundos geridos pelo governo federal não passível de contingenciamento. Com o FUNPEN, recursos foram transferidos para os Fundos Estaduais para a edificação de presídios. A legislação permite a construção sem licitação. Isso significa que, em nome da situação emergencial e desumana que vivenciamos, o Estado aceitou o risco de desvios mais facilitados de recursos. Contudo, o índice de execução foi muito baixo: em 2017, o Governo distribuiu cerca de R \$ 1,2 bilhão, mas apenas 1\% foi executado; em 2018, a execução não chegou a $4 \%$ e quase nenhuma vaga foi criada, mesmo com todos os recursos disponibilizados (MARIZ, 2018).

A baixa efetividade tem diferentes causas: a falta de capacitação dos gestores estaduais e federais para construção de presídios, as regras para construção de presídios serem distantes da realidade do país, a inexistência de orientação técnica para atendimento aos editais e de empresas especializadas que atendam aos requisitos previstos, a ausência de modelos nacionais de projetos, o calendário eleitoral e até mesmo um preconceito em relação à destinação dos recursos para a melhoria do sistema carcerário em detrimento de outras áreas possíveis para realização de políticas públicas. Além disso, ainda que contem com recursos federais, Estados ficam receosos em cons- 
truir os presídios porque depois terão de contratar pessoal e equipamentos para fazer com que as novas unidades prisionais entrem em funcionamento. De acordo com levantamento realizado em 2017, apenas 3 Unidades da Federação (Acre, Goiás e Rio Grande do Norte) iniciaram a ampliação de vagas, enquanto as demais utilizaram os recursos para compra de equipamentos e custeio (MARIZ, 2018).

\section{A AÇÃO DO PODER JUDICIÁRIO: A APARENTE INEFETIVIDADE DAS AUDIÊNCIAS DE CUSTÓDIA}

A questão do Estado de Coisas Inconstitucional do Sistema Carcerário foi submetida à análise do STF por meio da ADPF $n^{\circ}$ 347/DF (BRASIL, 2015b), sob a relatoria do ministro Marco Aurélio, proposta pelo Partido Socialismo e Liberdade (PSOL). Houve pedido expresso para que se reconhecesse a inconstitucionalidade do Estado de Coisas no sistema penitenciário brasileiro. Em contrapartida, o autor da ação pediu ainda que fossem adotadas providências estruturais em face de lesões a preceitos fundamentais dos presos. Fundamentou-se o pedido, sobretudo, em face do quadro de omissões dos Poderes Públicos da União, dos Estados e do Distrito Federal.

Ao apreciar o caso, o Supremo Tribunal Federal indeferiu, por maioria, os pedidos de interpretação da lei processual para restringir a aplicação das prisões preventivas, mas reconheceu, em caráter liminar, o Estado de Coisas Inconstitucional (ECI) no sistema penitenciário brasileiro e assentou a necessidade de adoção de providências estruturais em face de lesões a preceitos fundamentais dos presos decorrentes de omissões dos Poderes Públicos. Reconhecer o ECI significa admitir inconstitucionalidade por omissão sob o prisma material no sistema penitenciário, caracterizado por violação de normas constitucionais de eficácia plena e aplicabilidade imediata garantidora de direitos fundamentais da população penitenciária.

Todavia, o Tribunal, de forma comedida, se restringiu a deferir o pedido cautelar para determinar aos juízes e tribunais que, observados os artigos 9.3 do Pacto dos Direitos Civis e Políticos e 7.5 da Convenção Interamericana de Direitos Humanos, realizem, em até 90 (noventa) dias, audiências de custódia, viabilizando o comparecimento do preso perante à autoridade judiciária no prazo máximo de 24 (vinte e quatro) horas contadas do recolhimento ao cárcere. Deferiu cautelarmente, ainda, a liberação do saldo acumulado do Fundo Penitenciário Nacional para que se cumpra a finalidade para o qual foi criado.

Deixar de decidir o pedido de mérito abrangente constante na petição inicial da ADPF n. ${ }^{o}$ 347 (BRASIL, 2015b) configurou hipótese de omissão inconstitucional por um não ato do próprio Poder Judiciário e violou o direito constitucional de acesso à justiça dos presos, diante de um quadro grave de violações de direitos fundamentais e que se agrava a cada dia ${ }^{5}$.

A judicialização da política pública prisional destinada à proteção dos direitos fundamentais dos presos, em sua dimensão objetiva, proporcionou ao Judiciário a oportunidade de cumprir uma decisão política fundamental do Estado. Ao deixar de atuar ativamente na distribuição de direitos fundamentais dos presos, o Judiciário trouxe para si parcela da responsabilidade do Estado de Coisas Inconstitucional no sistema prisional e diminuiu o acesso à justiça principalmente em relação à parcela mais carente dos presos. 
$\mathrm{O}$ acesso à justiça é requisito básico de direitos humanos. $\mathrm{O}$ acesso à justiça não se dá apenas na forma individual, mas também na forma difusa. $\mathrm{O}$ acesso à justiça integral aos presos se enquadraria na terceira onda de acesso à justiça. Significaria tutelar interesses de uma população não representada ou mal representada. Conforme discorrem Cappelletti e Garth (1988, p. 68):

O novo enfoque de acesso à Justiça, no entanto, tem acesso muito mais amplo. Essa "terceira onda" de reforma inclui a advocacia, judicial ou extrajudicial, seja por meio de advogados particulares ou públicos, mas vai além. Ela centra sua atenção nas instituições e mecanismos, pessoas e procedimentos utilizados para processar e mesmo prevenir disputas nas sociedades modernas. Nós o denominamos “enfoque do acesso à Justiça” por sua abrangência.

O Judiciário poderia ter interferido de forma mais incisiva na política prisional. Caso assim agisse, possibilitaria melhorias nas condições de uma população composta por pessoas menos favorecidas, promoveria profundas alterações estruturais no sistema prisional em medida mais abrangente, tal como a pretensão deduzida em juízo pelo partido político postulante.

Em outros países, a obviedade da necessidade de apresentação imediata do preso à autoridade judicial não gerou a necessidade de etiquetar tal procedimento. Trata-se de Direito Humano. Em estudo de Direito Comparado para subsidiar o PLS 554/2011, levado a efeito por Weis e Fragoso (2012) pelo Núcleo Especializado de Cidadania e Direitos Humanos da Defensoria Pública do Estado de São Paulo no ano de 2012, verifica-se que, em outros países, o prazo para apresentação do preso ao juiz varia em média entre 24 e 48 horas (Reino Unido, França, Alemanha, Portugal, Suécia e África do Sul). Na Espanha, o prazo é de 72 horas e no Reino Unido e na França pode ser prorrogado até 96 horas ou 120 horas para circunstâncias especiais sob suspeita de terrorismo, no segundo caso. Na Argentina, o prazo é de apenas 6 horas.

Vigorava no Brasil o procedimento cartorial de mero encaminhamento do auto de prisão em flagrante para análise do juiz. Inicialmente, pensou-se nominar o referido procedimento de audiência de garantia ou, como o STF chegou a indicar, audiência de apresentação. Conforme ressaltado no Estudo sobre a obrigatoriedade de apresentação imediata da pessoa presa ao juiz: comparativo entre as previsões dos tratados de Direitos Humanos e do projeto de Código de Processo Penal, também elaborado pelo Defensor Público Carlos Weis (2002), a simples remessa de notificação de prisão não substitui o comparecimento pessoal perante o juiz, entretanto, pelo entendimento da Corte Interamericana de Direitos Humanos no caso Tibi $v$. Equador:

118. Este Tribunal estima necesario realizar algunas precisiones sobre este punto. En primer lugar, los términos de la garantía establecida en el artículo 7.5 de la Convención son claros en cuanto a que la persona detenida debe ser llevada sin demora ante un juez o autoridad judicial competente, conforme a los principios de control judicial e inmediación procesal. Esto es esencial para la protección del derecho a la libertad personal y para otorgar protección a otros derechos, como la vida y la integridad personal. El hecho de que un juez tenga conocimiento de la causa o le sea remitido el informe policial correspondiente, como lo alegó el Estado, no satisface esa garantía, ya que el detenido debe comparecer personalmente ante el juez o autoridad competente (CORTE, 2014, p. 63).

Pode-se dizer que a implantação das audiências de custódia revolucionou o processo penal brasileiro nos últimos anos. As audiências de custódia causaram a disruptura do modelo cartorial de comunicação das prisões provisórias até então vigente e promoveu humanização ao processo 
penal. Tem como gênese a finalidade de ajustar a legislação processual penal brasileira às exigências de diplomas internacionais, combater práticas violentas no ato de prisão em flagrante e reduzir a superpopulação carcerária provisória.

É efeito esperado pela implantação da audiência de custódia no sistema processual brasileiro a redução da superlotação carcerária, melhoria da apreciação e da fundamentação das prisões. Conforme esclarece Souza Netto (2016, p. 50):

Nesta conjuntura, a expectativa que recai sobre a audiência de custódia é não só de impedir atos de maus tratos ou tortura, mas principalmente de possibilitar uma discussão mais humana e adequada sobre a legalidade e necessidade da prisão preventiva, reduzindo o número de pessoas presas preventivamente sem necessidade e aprimorando a fundamentação das prisões.

\section{$[\ldots]$}

A audiência de custódia está intimamente ligada com a legalidade e a qualidade da motivação da decisão que decreta a prisão preventiva, pois possibilita-se, com a presença do Ministério Público e a defesa, uma análise mais profunda e fundamentada sobre o cabimento, no caso concreto, da medida extrema da segregação cautelar. A observância da audiência de custódia contribui para a redução da superpopulação carcerária e para uma melhora qualitativa na motivação dos decretos prisionais, pois substitui o juízo perfunctório de cognição sumária dos elementos contidos nos autos de prisão em flagrante, possibilitando à jurisdição uma motivação lastreada não só num espectro fático mais amplo, mas também no contraditório. O encontro com o acusado permite ao magistrado a compreensão mais aguçada do contexto e da necessidade da prisão, de forma mais humanizada e completa que a mera leitura da descrição dos dados do auto de prisão em flagrante, conforme era previsto no art. 306, $\S 1^{\circ}$, do Código de Processo Penal.

A determinação para que se implantasse as audiências de custódia é atitude de verdadeiro ativismo judicial, locução utilizada pela primeira vez em artigo de Kmiec (2004, p. 1446) sobre a Suprema Corte americana no período do New Deal, publicado em revista de circulação ampla. O ministro Barroso (2017) do Supremo Tribunal Federal explica que a ideia de ativismo por parte do Poder Judiciário está associada a uma participação mais ampla e intensa desse Poder na concretização dos valores e fins constitucionais, com maior interferência no espaço de atuação dos outros dois Poderes.

No caso de prisão em flagrante, o juízo a ser realizado na chamada audiência de custódia é complexo ou bifronte. Tal juízo não se destina apenas a controlar a legalidade do ato já realizado, mas também a valorar a necessidade e adequação da prisão cautelar para o futuro (PAIVA, 2016). Há uma atividade retrospectiva, voltada para o passado, com vista a analisar a legalidade da prisão em flagrante, e outra, prospectiva, projetada para o futuro, com o escopo de apreciar a necessidade e adequação da manutenção da prisão, ou de sua substituição por medida alternativa ou, até mesmo, a simples revogação sem imposição de medida cautelar (BADARÓ, 2014).

O juízo bifronte realizado pela autoridade judiciária no ato de apresentação do preso constitui importante instrumento de humanização do processo penal, pois aproxima o julgador do momento da prática da infração, oportuniza ao preso o direito de ser visto e ouvido e não apenas lido. Por fim, trata-se de importante filtro para se evitar o prolongamento de prisões inconvenientes ou até mesmo ilegais.

Ainda sobre o problema do excesso de presos no Brasil, importante estudo aponta que uma das evidências inaugurais do Plano Nacional de Política Criminal e Penitenciária, Elaborado em 
conformidade com o estabelecido pelo artigo 64, incisos I e II da Lei $\mathrm{n}^{\circ} 7.210$, de 11 de julho e 1984 (Lei de Execução Penal) (BRASIL, 1984) é a de que

\begin{abstract}
todos os estados possuem pessoas privadas de liberdade em estabelecimentos prisionais em situação de superlotação", de modo que o detalhamento do Plano reconhece que as condições carcerárias e a superlotação configuram violações à Constituição e à Lei de Execução Penal. Registra, ainda, que "há estados em que cerca de um terço da população prisional está em unidades com mais de quatro presos por vaga (MACHADO, SANTOS, 2018, p. 89-112).
\end{abstract}

Foi diante desse cenário que se implantou a audiência de custódia. Conforme anota Paiva (2018, p. 60), há um consenso na jurisprudência dos tribunais internacionais de Direitos Humanos no sentido de a definição do que se entende por "sem demora" deverá ser objeto de interpretação conforme as características especiais de cada caso concreto. Pretendeu-se dar ao preso acesso sem demora à jurisdição penal, permitindo-se a verificação mais célere da legalidade da prisão, bem como viabilizar a aplicação de medidas cautelares diversas da prisão para o caso analisado (CAMPOS, 2016, p. 15-20).

Será ilegal a prisão em flagrante que for convertida em prisão preventiva sem que seja observado o comando da apresentação imediata contido no art. 7(5) da Convenção Americana de Direitos Humanos e, como toda e qualquer prisão ilegal, deverá ser imediatamente relaxada pela autoridade judiciária, nos exatos termos do art. $5^{\circ}$, caput, inciso LXV, da Constituição (BADARÓ, 2014).

Há quem defenda, e isso pode ser lido em Garcia ([2015?], p. 6), que "não há violação alguma a direitos humanos quando a lei autoriza que a "audiência de custódia" seja realizada por outro órgão distinto do judicial, como preconiza o art. 7, item 5 da $\mathrm{CADH}$, tornando absolutamente desnecessária a instituição de outro ato processual para a apresentação do preso ao juiz".

Pesquisa publicada em 2018 (BRASIL, [2018?]) revelou importantes indicadores. O trabalho se propôs a investigar os elementos estruturais e ideológicos que fomentam o uso abusivo da prisão provisória no Brasil, mais especificamente em seis estados da Federação: Distrito Federal, Rio Grande do Sul, Paraíba, Tocantins, Santa Catarina e São Paulo.

Nos seis estados pesquisados houve crescimento do percentual de presos provisórios no período de dezembro de 2015 a junho de 2016. Para orientar a observação das audiências de custódia nas seis cidades contempladas na pesquisa, foi elaborado formulário de coleta para a sistematização dos dados gerais e a comparação entre as cidades.

Com o formulário, a pesquisa revelou dados coletados durante as audiências. Constatou-se que o preso permaneceu algemado em $81 \%$ das audiências; os agentes de polícia estiveram presentes em $86,2 \%$ das audiências; em $72,5 \%$ dos casos o juiz explicou a finalidade da audiência e o direito ao silêncio foi mencionado em $48,3 \%$ dos casos. Em $60 \%$ das audiências o juiz pediu para o preso não relatar o mérito da prisão. De outro lado, o mérito foi explorado pelo juiz em $9 \%$ das audiências.

A pesquisa não esclareceu se os agentes de polícia presentes nas audiências eram os mesmos que efetivaram as capturas dos presos. É importante esclarecer esse ponto porque a presença física dos responsáveis pela captura nas audiências pode inibir relatos de eventuais casos de maus tratos contra os autuados em flagrante. 
Ainda sobre violência policial, em $75 \%$ dos casos os presos não a mencionaram, mas, quando ocorreu, $73 \%$ dos casos foram atribuídos a policiais militares, $11 \%$ aos policiais civis e $10 \%$ alegaram terem sofrido violência por parte da população civil, quando a prisão foi executada por civis. Adverte Baratta que

pesquisas empíricas têm colocado em relevo as diferenças de atitude emotiva e valorativa dos juízes em face de indivíduos pertencentes a diversas classes sociais. Isto leva os juízes, inconscientemente, a tendências de juízos diversificados conforme a posição social dos acusados, e relacionados tanto à apreciação do elemento subjetivo do delito (dolo, culpa) quanto ao caráter sintomático do delito em face da personalidade (prognose sobre a conduta futura do acusado) e, pois, à individualização e à mensuração das penas destes pontos de vista (BARATTA, 2011, p. 177).

Alertamos que tal tendência pode impactar diretamente no número de liberdades provisórias concedidas nas audiências de custódia. Ainda segundo o autor a respeito do perfil dos presos apresentados nas audiências de custódia, a referida pesquisa revelou que $90 \%$ são do sexo masculino, $65 \%$ se declararam pretos ou pardos bem como aproximadamente metade possuía antecedentes criminais. Em relação ao tipo penal, o roubo foi o crime mais praticado.

Gráfico 5: Perfil dos autuados em 6 Estados- Pesquisa CNJ/2016

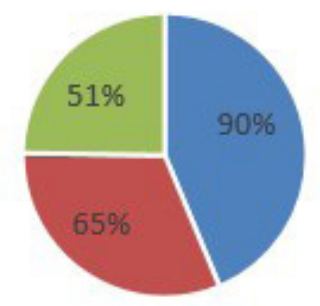

- Masculinos - Pretos ou pardos = Antecedentes Criminais

Fonte: Elaboração própria.

É importante mencionar algumas peculiaridades de cada localidade pesquisada. A pesquisa constatou que em São Paulo não são realizadas audiências aos finais de semana e os autos de prisão em flagrante nesse período são apreciados por juízes em regime de plantão. Dessa forma, as pessoas presas durante os finais de semana não são apresentadas às audiências de custódia (BRASIL, 2018, p. 19). 
Gráfico 6: Audiências de custódia em São Paulo - 2018

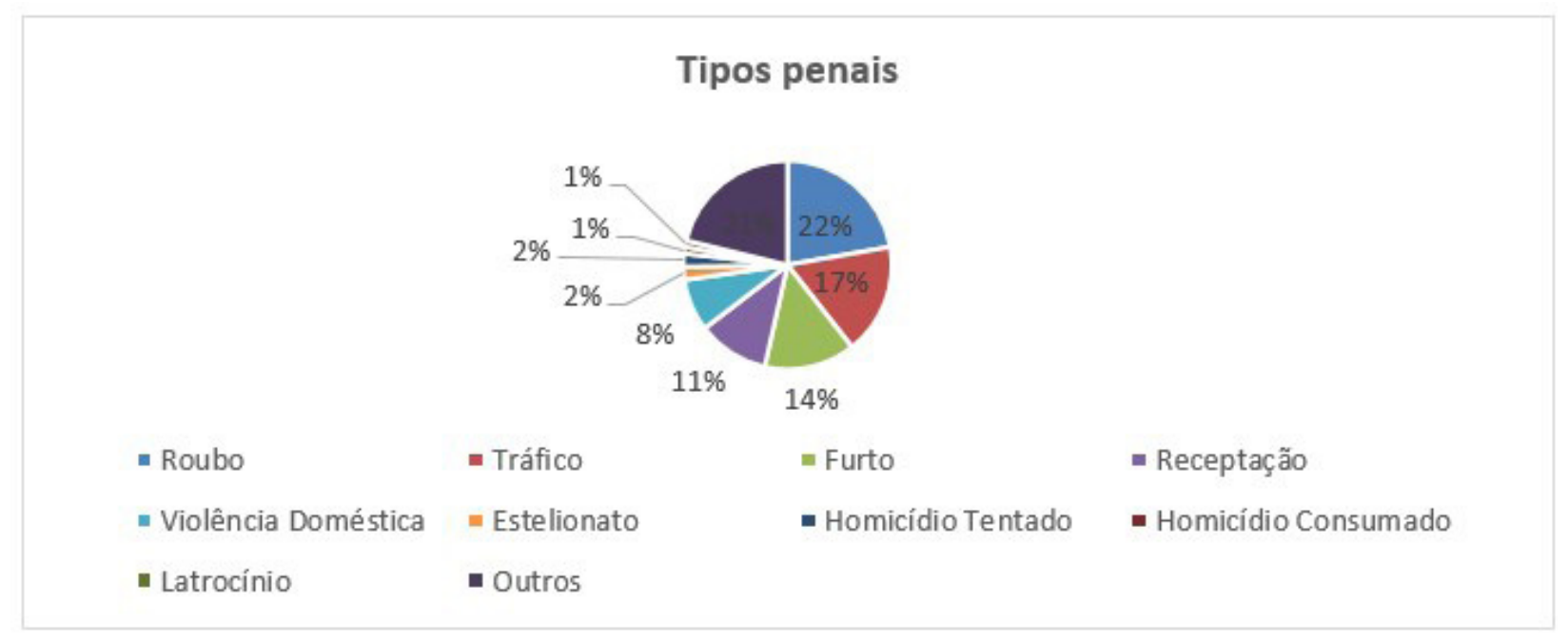

Fonte: Elaboração própria.

Em Porto Alegre, a autuação do Plantão Judiciário da Comarca funciona como importante filtro, tendo em vista que há muitos casos de revogação da prisão pelo juiz de plantão. Assim, o número de presos a serem encaminhados às audiências de custódia é reduzido drasticamente. Esse fato pode explicar o motivo de o Rio Grande do Sul ser, segundo dados do CNJ, o Estado da Federação onde há maior percentual $(84,83 \%)$ de prisões preventivas decorrentes de apresentação de presos às audiências de custódia (BRASIL, 2018, p. 21).

Em outra pesquisa, o Conselho Nacional de Justiça divulgou em sua página eletrônica informações consolidadas de todas as Unidades da Federação referentes às audiências de custódia ocorridas no período de 04/05/2015 a 30/06/2016. Os dados disponíveis revelam se as prisões submetidas às audiências permaneceram sob o título prisional preventivo ou se houve concessão de liberdade provisória aos presos. Há também dados indicadores de alegação da ocorrência de violência policial no ato prisão, considerando-se desde a captura até o momento da apresentação do preso na audiência de custódia, bem como do percentual de presos encaminhados ao serviço social de cada Unidade Federada (BRASIL, 2017).

Algumas informações chamam atenção devido à sua discrepância entre Unidades da Federação do mesmo país. Em apenas cinco Estados (Amapá, Bahia, Distrito Federal, Mato Grosso e Santa Catarina) houve maior número de liberdades provisórias concedidas do que prisões preventivas confirmadas. A Bahia é o Estado com maior índice (61,25\%) de concessão de liberdade provisória.

No extremo oposto, encontra-se o Estado do Rio Grande do Sul onde apenas $15,17 \%$ dos presos foram provisoriamente libertados e $84,83 \%$ das prisões preventivas obtiveram confirmação durante as audiências. Não significa que a declaração de inconstitucionalidade das condições prisionais do Brasil constitui motivo para não mais se prender. Contudo, a expectativa com as audiências de custódia era a de que a maior aproximação entre autoridades judiciais, os presos e os fatos proporcionasse mais utilização de medidas cautelares diversas da prisão, reduzindo-se o número de presos expostos a um sistema ineficaz em relação à recuperação. Os motivos pelos quais isso ainda não aconteceu precisam ser mais estudados. 
No tocante às alegações de violência policial no ato da prisão, apenas no Mato Grosso do Sul não houve nenhum registro, ao passo que no Estado do Amapá foram relatados 1.958 casos de violência policial, correspondendo a $38 \%$ das audiências realizadas.

Em relação à prestação de assistência social ao preso, evidenciaram-se os Estados de São Paulo e do Rio de Janeiro nos quais as taxas de encaminhamento de presos submetidos às audiências de custódia ao serviço foram de 45,87\% e 35,85\%, respectivamente. Por outro lado, o destaque negativo ficou com o Estado do Ceará, onde não houve prestação de assistência social a nenhum preso apresentado à audiência de custódia no período considerado.

A despeito desses pontos negativos, as audiências de custódia romperam com o modelo cartorial e proporcionaram mais humanização ao processo penal. O desafio que se coloca é fazer com que as audiências de custódia não tenham existência meramente protocolar. Reflexões como se o prazo de 24 horas para apresentação do preso à autoridade judicial é razoável, a maneira de computá-lo e consequências de sua eventual extrapolação; a de realização de audiência de custódia por videoconferências em prol da segurança do preso e dos policiais e da redução de custos em contrapartida ao aspecto humanitário; eventual alteração no papel da autoridade policial ao analisar a possibilidade de decretação de medidas cautelares diversas da prisão em caso de flagrante delito, sob a condição de convalidação pelos magistrados no prazo de apresentação do preso, bem como se o mérito da prisão poderia ou não ser apreciado nas audiências de custódia são fatores cujas análises merecem estudo e reflexão.

Roxin (2008, p. 18-19) ao refletir se o direito penal do futuro seria mais suave ou mais severo, foi taxativo ao afirmar que o desenvolvimento político-criminal deve afastar-se ainda mais da pena privativa de liberdade. Para ele, não se pode aprender a viver em liberdade e respeitando a lei através da supressão da liberdade; a perda do posto de trabalho e a separação da família que decorrem da privação da liberdade possuem ainda maiores efeitos dessocializadores. Consignou que, assim como na Alemanha, no futuro, a tendência será pelo maior uso da pena de multa, pois, afora a flagrante inefetividade da pena privativa de liberdade, a força preventiva do direito penal não depende da dureza da sanção, e sim de o Estado reagir ou não de modo reprovador. Nessa senda, Carnelutti pondera que: Talvez a batalha não seja pela reforma da legislação, para a reforma do costume. A
legislação, especialmente com as modificações mais recentes, faz pelo detento aquilo que
pode. Não é necessário pretender tudo do Estado. Infelizmente, este é um dos hábitos
que cada vez mais se consolidam entre os homens; e também este é um aspecto da crise
da sociedade. Sobretudo, não se deve pedir ao Estado aquilo que o Estado não pode dar
[...] até certo ponto o problema do delito e da pena deixa de ser um problema judiciário
para seguir somente como um problema moral. Cada um de nós está comprometido,
pessoalmente, na redenção do culpado, e por isso somos responsáveis. A dar-lhes, em
última análise, tal consciência, e a fazê-los sentir tal responsabilidade são dirigidas estas
discussões (CARNELUTTI, 2009, p. 79 ).

\section{CONCLUSÕES}

Passados pouco mais de quatro anos da implantação das audiências de custódia, as instituições públicas divergem e ainda não possuem números precisos da população prisional brasileira. $\mathrm{O}$ 
Supremo Tribunal Federal determinou a liberação de recursos públicos para a melhoria das condições da população carcerária. Contudo, nota-se que muito pouco ou nada foi concretizado, mesmo com a liberação de vultuosos recursos. O Poder Executivo Federal destinou recursos aos Estados, que não disponibilizaram novas vagas ou melhoraram as condições de cumprimento de pena. $\mathrm{O}$ Legislativo apenas aumenta a incidência do direito penal, a gravidade das penas e das formas de cumprimento. No Judiciário, segundo os dados disponíveis pelos órgãos oficiais, a implantação das audiências de custódia não contribuiu significativamente para a redução do número de presos no Brasil tampouco suavização do quadro de violações de direitos fundamentais no sistema prisional brasileiro.

\footnotetext{
Diante da omissão histórica dos Poderes Públicos, espera-se do Judiciário o monitoramento da situação carcerária no país, seguida de subsequente determinação para que os administradores públicos implementem propostas e metas voltadas à redução da superlotação dos presídios, à contenção e reversão do processo de hiperencarceramento existente no país, à diminuição do número de presos provisórios, à adequação das instalações e alojamentos dos estabelecimentos a fim de que se concretize o postulado da dignidade da pessoa humana presente na Carta Magna brasileira.
}

\section{NOTAS}

1 Os números foram extraídos de levantamento realizado pelo Departamento Penitenciário Nacional (Depen) na ocasião em que pretendia atualizar a taxa de ocupação nas unidades prisionais brasileiras. O Levantamento Nacional de Informações Penitenciárias (InfoPen) é atualizado pelos gestores dos estabelecimentos prisionais desde 2004 e sintetiza informações sobre os estabelecimentos penais e a população prisional.

2 Sistema de Informações estatísticas do sistema penitenciário brasileiro, que é atualizado pelos gestores dos estabelecimentos prisionais desde 2004, sintetizando informações sobre os estabelecimentos penais e a população prisional.

3 Subsidiariedade como viés do direito penal mínimo ou equilibrado, no sentido de que somente caberá ao Estado, por meio do direito penal, a resolução de um conflito se nenhum outro meio civil for capaz de solucioná-lo.

4 Relatório Global sobre Assentamentos Humanos do Programa das Nações Unidas para Assentamentos Urbanos (UN-Habitat), divulgado pela Organização das Nações Unidas (ONU).

$5 \mathrm{O}$ acesso à íntegra da petição da ADPF n. ${ }^{\circ}$ 347/DF encontra-se disponível em: https://bit.ly/2NGyVPo.

\section{REFERÊNCIAS}

AGÊNCIA CNJ de Notícias. Levantamento dos Presos Provisórios do País e Plano de Ação dos Tribunais. Brasília, 2017. Disponível em: https://bit.ly/2jhaE8T. Acesso em: 8 maio 2018.

AUDIÊNCIA de Custódia. Conselho Nacional de Justiça. Brasília, 2015. Disponível em: http://bit.ly/2YZz2zb. Acesso em: 8 ago. 2019.

BADARÓ, Gustavo Henrique Righi Ivahy. Parecer prisão em flagrante delito e direito à audiência de custódia. São Paulo: Academia Edu, 2014. Disponível em: https://bit.ly/2QRQbCU. Acesso em: 9 jul. 2018.

BARATTA, Alessandro. Criminologia Crítica e Crítica do Direito Penal: introdução à sociologia do direito penal. 6. ed. Rio de Janeiro: Revan: Instituto Carioca de Criminologia, 2011. 
BARROSO, Luís Roberto. Countermajoritarian, Representative, and Enlightened: The roles of constitutional tribunals in contemporary democracies. Revista Direito e Práxis, Rio de Janeiro, v. 9, n. 4, 2017.

BRASIL. Conselho Nacional de Justiça. Audiências de Custódia, Prisões Provisórias e Medidas Cautelares: obstáculos institucionais e ideológicos à efetivação da liberdade como regra. [S.l.: s.n.], [2018?]. Disponível em: http://bit.ly/34uDTaX. Acesso em: 9 jul. 2018.

BRASIL. Conselho Nacional de Justiça. Dados estatísticos/mapa de implantação. Brasília, 2017. Disponível em: https://bit.ly/1V1Dqno. Acesso em: 09 jul. 2018.

BRASIL. Conselho Nacional de Justiça. Cadastro Nacional de Presos. Brasília, [2019?]. Disponível em: https://bit.ly/2F2wcvX. Acesso em: 13 jul. 2018.

BRASIL. Conselho Nacional de Justiça. Relatório Analítico Propositivo: Justiça Pesquisa: Direitos e garantias fundamentais: Audiência de Custódia, Prisão Provisória e Medidas Cautelares: obstáculos institucionais e ideológicos à efetivação da liberdade como regra. Brasília: Conselho Nacional de Justiça, 2018. Disponível em: http://bit.ly/2YbN7ZX. Acesso em: 16 jul. 2019.

BRASIL. Conselho Nacional de Justiça. Resolução $n^{\circ} 213$ de 15/12/2015. Dispõe sobre a apresentação de toda pessoa presa à autoridade judicial no prazo de 24 horas. Brasília, 2016. Disponível em: http://bit. ly/2Yi7pkx. Acesso em: 31 jul. 2019

BRASIL. Conselho Nacional do Ministério Público. Sistema Prisional em Números. Brasília, 2015. Disponível em: https://bit.ly/2SkLd2z. Acesso em: 12 jul. 2018.

BRASIL. Lei $n^{\circ} 12.015$, de 7 de agosto de 2009. Altera o Título VI da Parte Especial do Decreto-Lei no 2.848 [...] e revoga a Lei no 2.252, de 1 o de julho de 1954, que trata de corrupção de menores. Brasília: Presidência da República, 1990. Disponível em: http://bit.ly/35KNj2a. Acesso em: 5 ago. 2018.

BRASIL. Lei $n^{\circ}$ 7.210, de 11 de julho de 1984. Institui a Lei de Execução Penal. Brasília, 1984. Disponível em: https://bit.ly/1QOAeWs. Acesso em: 13 ago. 2018.

BRASIL. Lei n 8.072/90. De 25 de julho de 1990. Dispõe sobre os crimes hediondos [...] e determina outras providências. Brasília: Presidência da República, 1990. Disponível em: http://bit.ly/2XZB5jU. Acesso em: 4 ago. 2018.

BRASIL. Ministério da Justiça e Cidadania. Secretaria de Assuntos Legislativos. Série Pensando o Direito. Brasília, 2015a. Disponível em: https://bit.ly/2HdELJQ. Acesso em: 6 ago. 2018.

BRASIL. Ministério da Justiça e Segurança Pública. Levantamento Nacional de Informações Penitenciárias. Brasília, 2017a. Disponível em: https://bit.ly/2vQYypP. Acesso em: 12 jul. 2018

BRASIL. Ministério da Justiça e Segurança Pública. Levantamento Nacional de Informações Penitenciárias Infopen - Junho 2014. Brasília: Departamento Penitenciário Nacional, 2014. Disponível em: https://bit.ly/ 2vQYypP. Acesso em: 12 jul. 2018.

BRASIL. Supremo Tribunal Federal. Acórdão de julgamento da Arguição de Descumprimento de Preceito Fundamental $n^{\circ}$ 347. Brasília, 2015b. Disponível em: https://bit.ly/2NGyVPo. Acesso em 13 jul. 2018.

CAMPOS, Carlos Alexandre de Azevedo. O Estado de Coisas Inconstitucional. Salvador: JusPODIVM, 2016.

CAMPOS, Carlos Alexandre de Azevedo. Estado de Coisas inconstitucional e o Litígio Estrutural. Consultor Jurídico, São Paulo, 2015. Disponível em http://bit.ly/2rzmYWa. Acesso em: 5 ago. 2018.

CAPPELLETTI, Mauro; GARTH, Bryant. Acesso à justiça. Tradução de Ellen Gracie Northfleet. Porto Alegre: Sérgio Antônio Fabris Editor, 1988.

CARNELUTTI, Francesco. As misérias do processo penal. 3. ed. Campinas: Russel Editores, 2009.

CAZARRÉ, Marieta. Ranking da Paz Mundial. Lisboa: Agência Brasil, 2018. Disponível em: https://bit. ly/2JennWe. Acesso em: 11 jul. 2018. 
CONSELHO NACIONAL DE JUSTIÇA. Regras de Tóquio: Regras mínimas padrão das nações unidas para a elaboração de medidas não privativas de liberdade. Brasília: CNJ, 2016.

CORTE INTERAMERICANA DE DERECHOS HUMANOS. Caso Tibi Vs. Ecuador. Sentencia de 07 de septiembre de 2004 (Excepciones Preliminares, Fondo, Reparaciones y Costas). Ecuador, 2004. Disponível em: http://bit.ly/33wdbNQ. Acesso em: 8 ago. 2018.

FERRAJOLI, Luigi. Direito e razão: teoria do garantismo penal. São Paulo: Revista dos Tribunais, 2002.

FÓRUM Brasileiro de Segurança Pública. Crimes contra a dignidade sexual. São Paulo, [2016?]. Disponível em: https://bit.ly/2sreHRk. Acesso em: 05 ago. /08/2018

GARCIA, Gustavo Assis. A falácia da audiência de custódia. [S.1.: s.n.], [2015?]. Disponível em: http://bit. ly/37N2EkX. Acesso em: 10 ago. 2018.

GOMES, Luiz Flávio; MOLINA, Antonio García-Pablos de. Criminologia. 8. ed. rev., at., ampl. São Paulo: Revista dos Tribunais, 2012.

JAKOBS, Güinter. Direito Penal do Inimigo: noções e críticas. 3. ed. Porto Alegre: Livraria do Advogado, 2008 .

KMIEC, Keenan D. The origin and current meanings of 'judicial activism', California Law Review, v. 92, n. 1441, p. 1441-1478, 2004.

LISZT, Franz von. Der Zweckgedanke im Strafrecht. In: LISZT, Franz von. Strafrechtliche Aufsätze und Vorträge. Berlin: Walter de Gruyter \& Co, 1905. v. I.

MACHADO, Bruno Amaral; SANTOS, Rafael Seixas. Constituição, STF e a política penitenciária no Brasil: uma abordagem agnóstica da execução das penas. Rev. Bras. Políticas Públicas, Brasília. v. 8, n. 1, 2018.

MARIZ, Renata. Estados gastam só $1 \%$ da verba disponibilizada para sistema carcerário, Rio de Janeiro, 2017. Disponível em: https://glo.bo/2g4nX8p. Acesso em: 1 ago. 2018.

NOTÍCIAS STF. Voto-vista. Brasília, 2017. Disponível em: https://bit.ly/2ldX7Mt. Acesso em: 11 jul. 2018.

NUCCI, Guilherme de Souza. Leis penais e processuais penais comentadas. São Paulo: Revista dos Tribunais, 2013.

NUCCI, Guilherme de Souza. Os mitos da audiência de custódia. Gen Jurídico, São Paulo, 2015. Disponível em: http://bit.ly/2OpWjE6. Acesso em: 3 ago. 2018.

NUCCI, Guilherme de Souza. Prisão e Liberdade: as reformas processuais penais introduzidas pela Lei 12 . 403, de 4 de maio de 2011. 2. ed. São Paulo: Revista dos Tribunais, 2012.

PAIVA, Caio. Audiência de Custódia e o Processo Penal Brasileiro. 3. ed. Belo Horizonte: CEI, 2018.

PAIVA, Caio. Audiências de custódia deveriam admitir atividade probatória. Consultor Jurídico. São Paulo, 2016. Disponível em: http://bit.ly/2OuXceT. Acesso em: 2 ago. 2018.

POWE JR. Lucas A. The Warren Court and American Politics. Cambridge: Harvard University Press, 2000.

PRADO, Rodrigo Murad do. Fundamentos do Direito Penal Mínimo: uma abordagem criminológica. Rio de Janeiro: Lumen Juris, 2014.

ROXIN, Claus. Estudos de direito penal. Tradução de Luís Greco 2. ed. Rio de Janeiro: Renovar, 2008.

SACHSIDA, Adolfo; MENDONÇA, Mario Jorge Cardoso de. Combatendo homicídios no Brasil: o que funciona em São Paulo funciona na Bahia? Rio de Janeiro: IPEA, 2014. Disponível em: https://bit.ly/2AQ5GWz. Acesso em: 7 jul. 2018

SOUZA NETTO, José Laurindo de. Aspectos relevantes sobre a audiência de apresentação do preso. Revista Judiciária do Paraná, Curitiba, ano XI, n. 11, p. 47-58, maio 2016.

SUXBERGER, Antônio Henrique Graciano. O Encarceramento em Massa na Agenda do Desenvolvimento Sustentável das Nações Unidas: Consequências para a Ação Penal no Brasil. Revista Internacional CONSINTER de Direito, v. 3, p. 1, 2016. 
SUXBERGER, Antônio Henrique Graciano; LIMA, José Wilson Ferreira. O Processo Penal e a Engenharia de Controle da Política Criminal. Revista Brasileira de Políticas Públicas, v. 7, n. 1, p. 277-293, 2017.

TAVÓRA, Nestor; ALENCAR, Rosmar Rodrigues. Curso de Direito processual penal. Salvador: Juspodivm, 2016.

VARELLA, Marcello. D.; OLIVEIRA, Clarice G.; MOESCH, Frederico. Salto digital nas políticas públicas: oportunidades e desafios. Revista Brasileira de Políticas Públicas, v. 7, n. 3, p. 560-583, 2017.

VASCONCELLOS, Vinícius Gomes de. Audiência de custódia no processo penal: limites cognitivos e regra de exclusão probatória. IBCCrim, boletim 283, junho/2016.

WAISELFISZ, Julio Jacobo. Mapa da violência 2016: homicídios, por arma de fogo no Brasil. Rio de Janeiro: Flacso, 2015. Disponível em: https://bit.ly/2bVB1fk. Acesso em: 7 jul. 2018.

WEIS, Carlos; FRAGOSO, Nathalie. Apresentação do preso em juizo: Estudo de direito comparado para subsidiar o PLS 554/2011. São Paulo: Defensoria Pública do Estado de São Paulo, 2012. Disponível em: https://bit.ly/2DcKSud. Acesso em: 5 ago. 2018.

ZAFFARONI, Eugenio Raúl; PIERANGELI, José Henrique. Manual de direito penal brasileiro: parte geral. São Paulo: Revista dos Tribunais, 2015.

ZACKSESKI, Cristina; MACHADO, Bruno Amaral; AZEVEDO, Gabriela. Dimensões do encarceramento e desafios da política penitenciária no Brasil. Revista Brasileira de Ciências Criminais, São Paulo, ano 24, vol. 126, dez. 2016.

Data de submissão do artigo: Janeiro de 2019

Data de aceite do artigo: Novembro de 2019 